\title{
Distributive principles of economic justice: an Islamic perspective
}

\author{
Zakiyuddin Baidhawy \\ State Institute of Islamic Studies (STAIN) Salatiga, Indonesia \\ E-mail:profetika@yahoo.com
}

\begin{abstract}
Poverty and impoverishment in the world currently continue to increase as a result of distributive justice systems and its principles that became the basis of contemporary economics did not succeed in allocating and distributing resources justly. Based on this problem, this study aimed at describing the Islamic response to the problem of distributive injustice, and how necessarily the state played a role in upholding distributive justice. Through the thematic-induction method and the synthetic analysis, the study finds out several findings as follows. Firstly, Islam formulated three principles of distributive justice as follows: 1) the Distribution of natural and the environmental resources was in the framework of participation; 2) the Redistribution of the wealth and the income were joint responsibility of ascertaining social security, the increase in the capacity and the authority for them who were disadvantage; and 3) the Role of the state was certainty that was complementary for the ethical market in order to guarantees the sense of justice and the achievement of public welfare. Secondly, according to Islam, the process of the redistribution of the wealth and the income aimed at giving social security on the fulfillment of basic needs for the poor; strove for the increase in the capacity through education and skills; and increased the poor's bargaining position through their participation in decision making that was linked with their interests and the control on its implementation. Thirdly, the intention of
\end{abstract}


establishing justice was to gain both individual and public welfare and the happiness (al-falāh).

Kemiskinan dan pemiskinan di dunia kontemporer terus meningkat sebagai akibat sistem keadilan distributif dan prinsip-prinsipnya yang menjadi basis ekonomi saat ini tidak berhasil dalam mengalokasikan dan memeratakan sumber daya secara adil. Berdasarkan masalah ini, kajian ini bertujuan untuk menjelaskan respon Islam atas problem ketidakadilan distributif, dan bagaimana seharusnya negara ambil peranan dalam menegakkan keadilan distributif. Melalui metode induksi-tematik dan analisis sintetik, kajian ini menemukan beberapa hal penting antara lain. Pertama, Islam telah merumuskan tiga prinsip keadilan distributif sebagai berikut: 1) pemerataan sumber daya alam dan lingkungan dalam kerangka partisipasi; 2) redistribusi kekayaan dan pendapatan dalam rangka memastikan keamanan sosial, dan meningkatkan kapasitas dan otoritas bagi mereka yang kurang/tidak beruntung; dan 3) peran negara merupakan pelengkap bagi pasar yang etis dengan maksud untuk menjamin rasa keadilan dan tercapainya kesejahteraan publik. Kedua, menurut Islam, proses redistribusi kekayaan dan pendapatan bertujuan untuk memberikan jaminan sosial bagi pemenuhan kebutuhan orang miskin; untuk meningkatkan kapasitas mereka melalui pendidikan dan pelatihan; dan meningkatkan posisi tawar kaum miskin melalui partisipasi dalam pengambilan keputusan yang berkaitan langsung dengan kepentingan mereka, serta kendali atas pelaksanaan keputusan tersebut. Ketiga, maksud penegakkan keadilan ialah untuk mewujudkan kesejahteraan sekaligus kebahagiaan individu dan publik.

Keywords: Distributive justice; Islam; Contemporary economy; Sense of happiness

\section{Introduction}

Recently economic injustice has become a universal problem faced by all contemporary systems. In almost all parts of the world and in all historical eras, there exists materialistic economic systems that result in bearing injustice. These systems usually come from extreme ideologies which has failed enough in bringing a better economic system to all 
participants. In the global scale, many people reject Capitalism that is without any regulations, Neo-liberalism which has resulted in poverty and massive impoverishment, and extreme Socialism.

The philosophical powers which have driven Capitalism, ${ }^{1}$ Socialism, ${ }^{2}$ Welfare State, ${ }^{3}$ and Neo-liberalism ${ }^{4}$ are still problematic especially in relation to economic justice - in ownership, production, consumption,

${ }^{1}$ Capitalism, which is in classic form said as laissez fair, has come down and the retention form is the modified Capitalism. It has 5 main characteristics 1) it views that wealth expansion can be accelerated, maximum production and need satisfaction as the preference is very important for human welfare; 2 ) it views that everyone is free to have their own private property; 3 ) it assumes that individual initiation and their decentralized decision making in a free market is the efficient requirement in allocating resources; 4 ) it disbelieves in the government role and collective values consideration in allocation efficiency and distributive justice; and 5) it claims that the fulfillment of private needs will automatically fulfill collective one. See: M. Umer Chapra, Islam and the Economic Challenge, Herndon: IIIT, 1992, chapter 1. In this case, Capitalism is considered as a sophisticated ideology as its responsive in repairing the errors assumed. Even there are some contra responses from the place where it was born and even bearing another antithesis namely Socialism, Capitalism still has a very great power and it survives. Thus, Fukuyama called it as the end of history. See Francis Fukuyama, The End of History and the Last Man, New York: Avon Books, 1992.

${ }^{2}$ Socialism and Marxism as antithesis of Capitalism are also incapable. Even, these ideologies experienced faster decline than predicted. This is due to the major inherent weaknesses appeared. First, this ideology implies disbelief on human capability to operate their private ownership in the barriers of social welfare. Every people having similar capacity as the consumers, workers, company managers, and civil servants will always be supported to reach their best for the social welfare without regarding to their private necessity. Second, government power holder will be in the hands of those having necessity, which is in line with social necessity. However, the reality is contrary to the fact where a group people controlling the government power will utilize the state's income and wealth for their own sake. Third, the great amount of public subsidy will be profitable to the haves and certain community only than to the poor having limited purchasing power. Norman Furniss and Timothy Tilton, The Case of Welfare State: From Social Security to Social Equality, Bloomington, Indiana: International Union Press, 1977, 42.

3There are two momentum in Welfare state: : After the Great Depression and the Second World War as the responses of challenging caused by Socialism and problems of the two momentums. To see the history of Welfare State, see Maurice Bruce, The Coming of the Welfare State. London: Batsford, 1968.

${ }^{4}$ The rising of economic Liberalism is primarily to struggle for leissez faire, it is a belief in maintaining private rights and ownership, and believing more towards market than state role in solving the social problems. See Mansour Fakih, Bebas dari Neo-liberalisme, Yogyakarta: Insist Press, 2003, 54-58. 
and especially distribution - and we need direct solution. It is important to solve the source of these problems rather than its artificial impacts. Thus, reformation on socio-economic structure and values of justice are needed.

In Islamic thought, justice is a moral value emphasized frequently in the Quran. More than one hundred verses about justice are mentioned in the Quran. In the holy Quran, there are also two hundred utterances warning to reject injustice. This reflects that Islam is very overt and strict in relation to justice.

The messages about justice in the Quran are very obvious and understandable. One of Allah's names is the Supreme of Justice (al'AdI); He creates the universe and all that exists within (macrocosmic) in justice, ${ }^{5}$ mankind (microcosmic) is also created in justice; ${ }^{6}$ also, the prophet and mankind duties such as the khalifah are to maintain justice in this world ${ }^{7}$ as well as in the field of economy.

The importance of maintaining justice in our lives is to ensure equality for all in order to reach good achievement and economic welfare. To achieve this goal, we can begin by applying and growing the aspects of aqidah and ethics for both individuals and social dimensions. ${ }^{8}$

The Islamic system tries to realize the principles of justice in economic activity by rejecting secular and sacred compartmentalization. Spiritualization and moralization on both individual and collective economic activity will promote the economic justice intended.

Topics of spiritualization and moralization in relation to economic activity show significant problems. The development of values on these

${ }^{5}$ QS. Al-Raḥmān 55: 7.

${ }^{6}$ QS. Al-Infițār 82: 7.

${ }^{7}$ QS. Sād 38: 26.

8 M. Quraish Shihab, Wawasan al-Qur'an: Tafsir Maudhu'i atas Pelbagai Persoalan Umat, Bandung: Mizan, 1996, 129. 
aspects needs long term efforts and comprehensive competence. The first step requires our belief in the aqidah of Islam as the way of life. The Quran and the Sunnah are the main sources of Islamic teaching and their internal values are 'taken for granted'. Furthermore, there are two ways used to develop these values, namely by the approaches of qawliyyah and kawniyyah. ${ }^{9}$ Related to the first approach, the Quran and the Sunnah should become the fundamental consideration in exploring these values. Thus, the intellectual efforts in studying the values of justice and reconstructing justice conceptions as the alternative solutions to injustice based on the Quranic values will be significant in this context.

Due to the importance of justice in economic systems and activities, this paper will elaborate the Quranic answers towards distributive injustice, the role of the government in overcoming this injustice, and its related goals and implications.

\section{Critics on the contemporary principles of justice}

Contemporary economic systems such as Capitalism, Socialism, Marxism, Welfare State, and Neo-liberalism- are based on certain theories of justice. Current discussion and debate on justice will result in some theories and principles of justice. Even when the followers have the same ideal of maintaining justice among society; they still have significant different ideas in determining the appropriate meaning and definition of justice. Theories of justice serving as the foundation of contemporary economic systems are as follows: Strict Egalitarianism ${ }^{10}$ which

\footnotetext{
${ }^{9}$ Qawliyyah approach which is normative-prescriptive, and kawniyyah approach which is positive-empirical are not contradictory and dichotomy. Both are important and completing each other. See M. Akhyar Adnan, Akuntansi Syariah: Arah, Prospek dan Tantangannya, Yogyakarta: UII Press, 2005, 4-7.

${ }^{10}$ For clearer explanation see Kai Nielsen,"Radical Egalitarian Justice: Justice as Equality" Social Theory and Practice (1979): 209-226.
} 
emphasizes collectivity and an equal basket of needs for each person; The Different Principle ${ }^{11}$ which focuses much more on overcoming inequality; Resource-Based Approaches ${ }^{12}$ which puts hard work as an important component in earning greater income and refusing subsidy for disadvantaged people; Welfare-Based Approaches ${ }^{13}$ which promote the greatest happiness for the greatest numbers; Desert-Based Approaches ${ }^{14}$ which emphasize rewarding effort and achievement (meritocration); and Libertarian Principles ${ }^{15}$ which agree that freedom, self-interest, and free market are needed (see details of justice principles in Table 1).

The principles evident in the six justice theories mentioned above contain some limitations in answering the problems of injustice. The limitations are as follows: first, in the problem of ownership the Strict Egalitarianism and Libertarian Principle are contradictory. The former advances collective ownership while the latter places more emphasis on private ownership and self-interest. Second, in the problem of resources, Libertarian Principle states that this world is initially un-owned. Thus, it is not important to debate how to treat the world.

Third, some justice theories focus too much on the fact and problems of economic justice without providing sufficient answers for

\footnotetext{
${ }^{11}$ See John Rawls, $A$ Theory of Justice, $22^{\text {nd }}$ printed, Cambridge, Massachusetts: The Belknap Press of Harvard University Press, 1997.

${ }^{12}$ Ronald Dworkin, "What is Equality? Part 1: Equality of Resources", Philosophy and Public Affairs, 10 (1981): 185-246; dan "What is Equality? Part 2: Equality of Welfare", Philosophy and Public Affairs, 10 (1981): 283-345.

${ }^{13}$ See Robert E. Goodin, Utilitarianism as a Public Philosophy, New York: Cambridge University Press, 1995.

${ }^{14}$ See David Miller, Social Justice, Oxford: Clarendon Press, 1976; David Miller, Market, State and Community, Oxford: Clarendon Press, 1989; dan Jonathan Riley,"Justice Under Capitalism", Market and Justice, John W. Chapman, ed., New York: New York University Press, 1989, 122162.

${ }^{15}$ Robert Nozick, Anarchy, State and Utopia, New York: Basic Books, 1974.
} 
justice problems. Resource-Based Approaches do not discuss social responsibilities for the disadvantaged and do not provide subsidies for those who get less income. Welfare-Based Approaches and Utilitarianism sacrifice the minority for the sake of majority interests and welfare; and the Desert-Based Approaches do not give sufficient answers to the question that "if people should be rewarded for their efforts and actual contribution to the society, who is responsible for the existence of the disadvantaged in the society?".

Four, in Strict Egalitarianism, if everyone should have the same level of material goods and services there will be a dilemma how to put reward to different effort and achievement?

Five, due to competition, free market morally needs a trusted instrument to allocate and distribute resources fairly. The facts shows that market power is not fully capable in fulfilling the duties of allocation and distribution fairly (equally). In such situations, who should be responsible for redistribution of resource for the disadvantaged people?

Six, essentially Rawls' Theory of Justice is concerned with inequality. This principle will merely answer how to overcome inequality, while the differences and its consequences will not be viewed as undeniable reality; difference cannot be viewed as a potential to usufruct (take and give the benefits) each other and as a starting point to get achievement. Finally, almost all the theories of justice mentioned above seem to focus on distributive justice, so that the other aspects of economic activities such as consumption and treatment of the natural and environmental resources receive less attention. 


\section{Table 1}

Contemporary Principles of Justice

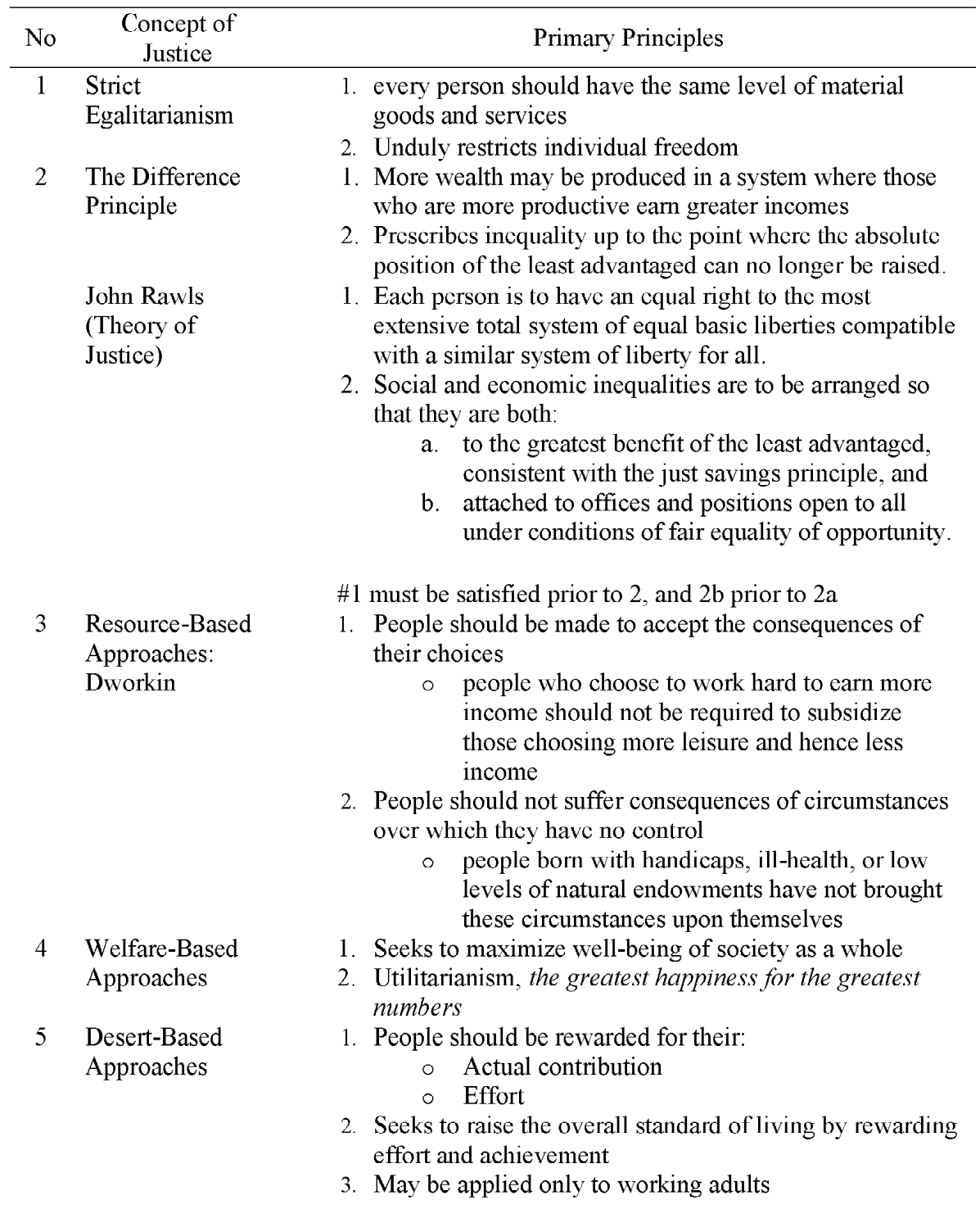


6

Libertarian

Principles:

Nozick
1. Pcople own themselves.

2. The world is initially un-owned.

3. You can acquire absolute rights over a disproportionate share of the world, if you do not worsen the condition of others.

4. It is relativcly casy to acquirc absolutc rights over a disproportionate share of the world.

5. Therefore: Once private property has been appropriated, a free market in capital and labor is morally required.

\section{Principles of distributive justice}

Discussions of distribution need to address the following questions: Toward whom are production activities directed? How is the national product distributed among different factors of production? How can the inequality caused by distribution be solved? These are the prime problems faced by societies of any adopted economic system.

Distribution- the Quran called as dülah ${ }^{16}$ - becomes the foundation for circulation of wealth, welfare, and income among society so that those things will not be concentrated in the hands of the haves. ${ }^{17}$ Beside the direct aforementioned statement, the Quran also mentions three actions which will prevent unequal distribution, such as prohibition on heaping wealth (al-iktināz), ${ }^{18}$ piling up the good things of this world (al-takāthur), ${ }^{19}$ and denunciation on wealth heaping and piling up wealth and laying it (jama'a mal wa 'addadah). ${ }^{20}$

In running the distribution process, we need a legitimate base. This means we need particular criteria and determining principles, which are applicable for anyone who has a relationship with wealth and income. There are many possible criteria, which cause natural differences or

\footnotetext{
${ }^{16}$ QS al Hashr 59:7.

${ }^{17}$ Qs. Al-Hashr 59:7.

${ }^{18}$ Ibn Manzur, Lisān al-'Arab, vol 5, Beirut: Dār al-Ṣadr, 1990, 401-402.

${ }^{19}$ QS. Al Takāthur 102: 1.

${ }^{20}$ QS. Al Humazah 104: 1-2.
} 
different achievement among individuals. The criteria include exchange, ${ }^{21}$ needs, ${ }^{22}$ authority, ${ }^{23}$ and social systems or ethical values.

Elaboration on the aforementioned criteria of exchange and needs is different from the Desert-Based Approaches which view effort and actual contribution as distribution principles. According to the Quran, the former criteria is acceptable as everyone will get something due to his/her effort. However the actual contribution is not fully acceptable due to some reasons: in one's wealth and property, there is still a certain part owned by the disadvantaged; people who have responsibility to preserve the household for the family (married person) will get greater subsidy than the single person; people may sacrifice herself for others sincerely.

Distribution schema can be defined through some distributive parameters and policies guided by shariah with its economical implications. There are two types of distribution schemes. First, regulation of distribution over natural and environmental resources: 1) through partnership in solving individual difference caused by different quantities of productive assets, ${ }^{24}$ both public property and natural resources; 2) prohibition on the restriction of economic access ${ }^{25}$ as it is contradictory to partnership principles in taking the benefits of natural resources for un-owned and unproductive land; 3 ) the state may carry away unproductive land ${ }^{26}$ for productive goals through the mechanism of the turning over of private ownership (iqtāa $)^{27}$; 4) regulations on mines and public goods (water resources, forestry, and power resources) so that

\footnotetext{
${ }^{21} \mathrm{QS}$. al-Baqarah 2:275.

${ }^{22} Q S$. Hūd 11:6.

${ }^{23} \mathrm{QS}$. Hūd 11:3.

${ }^{24} \mathrm{QS}$. al-Zukhruf 43:32.

${ }^{25}$ Abu Daud, Sunan, kitāb al-kharāj wa al-Imārah wa al-fay', hadis no. 2679.

${ }^{26}$ Abu Daud, Sunan, kitāb al-kharāj wa al-Imārah wa al-fay', hadis no. 2671.

${ }^{27}$ Abu Daud, Sunan, kitāb al-kharāj wa al-Imārah wa al-fay', hadis no. 2658.
} 
these are used for public welfare ${ }^{28}$; 5) efficient effort in utilizing water resource and renewable resources.

Second, regulation of the distribution of production (wealth and income), among others are: 1) to share surplus in using production capital ${ }^{29} ; 2$ ) inheritance is intended for equal distribution of wealth ${ }^{30}$ to the heirs of the deceased; 3) Zakat both paid individually and actively taken by the state is to maintain social solidarity ${ }^{31}$; 4) waqf is a foundation of social philanthropy functioning as the turning over of private ownership to public ownership by which its benefits are for the public welfare ${ }^{32}$; 5) to be accustomed to give other gift honestly33; 6) alfay $^{\prime 34}$ al-ghanimah ${ }^{35}$ and rikā $z^{36}$ for collective welfare.

Giving surplus of capital utilization - in the form of fixed assets strengthens the Quranic rejection towards Desert-Based Approaches, which oblige people to give any compensations of any production activities, as well as when capital surplus should be compensated with costs to the users. The wealth inheritance system gives argumentation for the Quranic refutation towards the statement of Desert-Based Approaches where everyone should get reward for his actual contribution. Inheritance distributes and transfers property and wealth of the deceased to his right- heirs without regarding whether or not they give actual contribution. Distribution of zakat is the denial to Nozick's Liber-

\footnotetext{
${ }^{28} \mathrm{Abu}$ Daud, Sunan, kitāb al-kharāj wa al-Imārah wa al-fay', hadis no. 2660.

${ }^{29}$ Muslim, Saḥịh, kitāb al-luqațah, hadis no. 3258.

${ }^{30}$ QS. al-Nisā' 4:7.

${ }^{31}$ al-Tawbah 9:60.

${ }^{32}$ QS. Ālu 'Imrān 3:92.

${ }^{33}$ Ibn Hajar al-Asqalani, Fatḥ al-Bārì Sharh Șaḥiḥ al-Bukhāri, Beirut: Dār al-Mu'arrafah, NA,

${ }^{34}$ QS. al-Hashr 59:6; see also in verse 7-10, which mention that part of our wealth is for Allah and His messengers, family, orphans, poor people, ibn sabill, faqï chased from his villages.

${ }^{35}$ QS. al-Anfāl 8:41.

${ }^{36}$ Turmudzi, Sunan, kitāb al-aḥkām 'an Rasūlillāh, hadith no. 1298.
} vol. V, 243. 
tarian Principle which states that any tax over income and welfare/ property (any levied taxes as well as zakat) imposed by the state is a violation of the exclusive rights of property because states let people own other people's right; tax can be said as violating the absolute selfinterest and it is unfair that someone works and other gets a part of his/her reward.

On the other hand, it is obvious that zakat is a rejection of DesertBased Approaches to actual contribution. Expending zakat from private ownership is legal and the mustahiq are also legal to obtain and own zakat without regarding their actual contribution. Different from Welfare-Based Approaches or Utilitarianism, which tried to maximize public welfare by sacrificing the minority, the institution of waqf works logically for public welfare (al-mașlahah al-āmmah). It means, for public interest, every individual may sacrifice his/her wealth or property for waqf honesty. In other words, individuals should sacrifice for society's welfare yet this does not mean in verse that for the sake of society's welfare the minority or individual is necessitated to sacrifice themselves.

Meanwhile the additional distribution scheme includes prohibition on usury as exploitation towards the poor ${ }^{37}$, prohibition on heaping wealth/ property, and prohibition on monopoly.

Even though the three distribution schemes mentioned above have been adopted, there are still poverties and impoverishment. These problems are also apparent in some contemporary justice principles such as The Different Principle and Rawls' theory of justice. Nozick's Libertarian Principle actually provides how to rectify past injustices, but he did not provide a systematic effort for the rectification of these injustices, and even he put the right to rectify the injustice to The Different Principle.

\footnotetext{
${ }^{37} Q$ S. Ālu 'Imrān 3:130; see also al-Rūm 30:39.
} 


\section{Redistribution for the poor: overcoming inequality}

It is obvious that the Quran has provisions for the poor and the oppressed. The population of new mustad'afin as a result of political economic and structural tendency for the last three decades, will increase in numbers moreover after the extension of the economic crisis period. This situation put the population to spread widely as subcultures, covering housing and job crisis, and great decrease on society expenditure.

Consequently, poverty and impoverishment today reflect more on poverty itself, and 'structural' oppression. Thus, it needs systematic redistribution processes to raise the disadvantaged from powerlessness, contingency and scarcity. Referring to that which is stated in the Quran in surah al-Anfāl 8: 26, the efforts to humanize their existence includes two aspects: social-charity service and social empowerment. The first means to fulfill their basic needs so that they can survive, while the second tries to raise their "capacity" and "authority" for sustainability.

Social security for fulfilling basic needs

Options for the mustad'afin can be demonstrated by giving aid to the disadvantaged to help them achieve their physiological and basic needs freely. This service and aid is purely social-charity. The goal is to help mustad'afin to get their emergency needs for clothing, foodstuff, and housing scarcities. Without the help of the advantaged, the existence of the disadvantaged will be in danger. Such social-charity aid, for example, is stated in surah al-Mā'ūn (107:1-7). This surah was descended in Mecca, exactly after the descend of al-Takāthur, it is surah which asserts the prohibition of piling up wealth in this life. The relation of these two surah is very close because surah al-Takāthur states that 
such an elitist life style of heaping property will make one apathetic. The same case is stated even more strictly in al-Mā'ūn. In this surah, God criticizes everyone who prays as "a liar" because he/she ignores and unawares to mustad'afin and they never want to help the poor for getting their better life.

The previous explanation underlines a fact that emergency services and help for acute poverty are in the form of providing basic needs such as feeding (it'ām), wearing (kiswah) and housing. ${ }^{38}$ These will secure survival. ${ }^{39}$

Responsibility for securing the basic and minimal needs of life will be shared (takāful) by some institutions so that this will no longer be a heavy burden. ${ }^{40}$ We need to know about the responsibilities on public expenditures, and how far we are allowed to take tax or zakat to support our basic and minimal needs. When the closer heirs cannot secure the fulfilling of basic needs because they are also included as the disadvantaged, intervention on public expenditure and zakat are needed.

The Quran obliges one to extend parts of one's wealth and property for maintaining the life of the poor and those who are not able to work. It is based on the rules of inheritance. ${ }^{41}$ Thus, maintaining the life of the poor who are not able to work is an obligation for the haves who will inherit their wealth and property.

\footnotetext{
${ }^{38}$ See also QS. Al-Nisā' 4:5; and al-Mā'idah 5:89.

${ }^{39}$ Security to survive is also emphasizes in hadis of the Prophet Muhammad: "From Abu Sa' id al-Khudri, from Nabi SAW said: "any Moslems giving clothes to the nude Moslems, Allah will give all kinds of plants from heaven, any Moslems giving food for the hungered Moslems, Allah will give any fruits from heaven, any Moslems giving water to the thirsty Moslem, Allah will give pure wine". Abu Daud, Sunan, kitāb al-Zakāh, hadith no. 1432.

${ }^{40}$ QS. al-Baqarah 2:215.

${ }^{41}$ QS. al-Nisā' 4: 7.
} 
To cope with such problems in contemporary contexts, it is proposed that this social security is supported by public expenditure. At the same time, an individual has the same right to find support from the available public expenditure. This case should become public policy, which is determined by the political system or state and it is possible to change at the appropriate time and place.

\section{Capacity Improvement}

"Capacity Improvement" is done by giving assets or chance for the mustad 'afin to get education, health services, and life skills. So, they will be strong physically and mentally. Cheap education, skill improvement, and simple health services will lead to improved quality of life, and then people can develop their potency and life skills significantly. Within this way the mustad `afin will have better bargaining position and they can increase their life skills as well. Ease of access to clean water is also a needed to improve quality of life. Thus, any economic activities limiting mustad 'afin from having access to clean water resources freely will be a serious violence toward public ownership. And this has been done by the Neo-liberalism that forces the privatization of cleaned water resources. 
Table 2

Comparison on distribution theories and their implications

\begin{tabular}{|c|c|c|}
\hline Theory & Principle & Implication \\
\hline $\begin{array}{c}\text { Strict } \\
\text { Libertarianism }\end{array}$ & $\begin{array}{l}\text { - } \text { self-interest } \\
\text { - } \text { absolute rights over } \\
\text { global distribution } \\
\text { which is } \\
\text { disproportional }\end{array}$ & $\begin{array}{l}\text { any tax over income and } \\
\text { welfare/property (any levied taxes as } \\
\text { well as zakat) imposed by state is a } \\
\text { violation towards self-interest because } \\
\text { states let people own other people's } \\
\text { rights. } \\
\text { Freedom to allow distributive injustice } \\
\text { and ignore their social responsibilities in } \\
\text { solving powerlessness, contingency and } \\
\text { scarcity of the disadvantaged. }\end{array}$ \\
\hline $\begin{array}{l}\text { Desert-Based } \\
\text { Approaches }\end{array}$ & $\begin{array}{l}\text { Any compensation in } \\
\text { economic activities }\end{array}$ & $\begin{array}{l}\text { Any capital operations in the form of assets } \\
\text { need compensation. }\end{array}$ \\
\hline $\begin{array}{l}\text { Welfare-Based } \\
\text { Approaches }\end{array}$ & $\begin{array}{l}\text { Maximize welfare for the } \\
\text { majority. }\end{array}$ & $\begin{array}{l}\text { For the sake of social welfare, the necessity } \\
\text { of minority is ignored. }\end{array}$ \\
\hline $\begin{array}{l}\text { Resource- } \\
\text { Based }\end{array}$ & $\begin{array}{l}\text { There is no obligation to } \\
\text { give subsidy to the }\end{array}$ & $\begin{array}{l}\text { - Everyone works and thinks about income } \\
\text { for their own sake only.; }\end{array}$ \\
\hline Approaches & $\begin{array}{l}\text { disadvantaged both } \\
\text { individually and } \\
\text { collectively. }\end{array}$ & $\begin{array}{l}\text { - Everyone is free from the consequences } \\
\text { of their environment. }\end{array}$ \\
\hline John Rawls & $\begin{array}{l}\text { Socio-economic inequality } \\
\text { needs such ordinance } \\
\text { therefore the inequality } \\
\text { will be profitable for } \\
\text { everyone }\end{array}$ & $\begin{array}{l}\text { - Improving conditions for the } \\
\text { disadvantaged can be achieved by } \\
\text { reducing the wealth of the advantaged. } \\
\text { It takes enormous cost to reach socio- } \\
\text { economic justice }\end{array}$ \\
\hline $\begin{array}{l}\text { The Quranic } \\
\text { Ethics }\end{array}$ & $\begin{array}{l}\text { - Natural and } \\
\text { environmental } \\
\text { resources' distribution } \\
\text { are in the framework } \\
\text { of participation????; } \\
\text { - Wealth and income } \\
\text { redistribution are } \\
\text { collective } \\
\text { responsibilities to } \\
\text { ensure the social } \\
\text { security, capacity } \\
\text { improvement, and } \\
\text { authority for the } \\
\text { disadvantaged. }\end{array}$ & $\begin{array}{l}\text { - Secure the fulfillment of basic needs. } \\
\text { Partnership in owning certain natural } \\
\text { resources will reduce disparity or } \\
\text { difference of income and wealth; } \\
\text { A harmony between self-interest and } \\
\text { social interest; individual welfare and } \\
\text { social welfare. } \\
\text { - To improve economic activities. }\end{array}$ \\
\hline
\end{tabular}

Authority improvement

The mustad'afin needs "authority improvement" in the process of decision making. The fulfillment of basic needs (clothing, foodstuff, and 
housing), outgoing access and education opportunities as well as skills, and cheap and simple health services are very important. However, this option for the poor will come into the political area. This will be more stable if the social empowerment also includes the involvement of the oppressed and disadvantaged people in determining their own needs and interest; in deciding policy together with other social groups. After the participation, the next effort is to put the mustad'afin in authoritative positions in relation to the implementation of important policies or decision. Participation in making a decision is not enough. Participation in the implementation itself will enable them to keep and maintain their own social-economic interests. Participation and direct control will lead them to have authority and power over the other social groups.

From this case, it can be viewed that the Islamic ethics are different from Rawls' principles which believes that based on equal prospect, education and skills are important for the disadvantaged to raise their condition. In the Islamic view, Rawls' offering only emphasizes how to improve capacity and ignores other important efforts such as the emergency physiological interest, authority improvement for the disadvantaged including participation and control in political processes of decision making and policy implementation.

\section{The role of the state}

The importance of the role of the state cannot be separated from discussions of contemporary economics. This problem relates to how the state takes positions in securing, maintaining, and regulating various ownerships. It becomes a determining issue in any contemporary economic system as well as the point differentiating one system from another. Capitalism based on Libertarian principles tends to give priority to individual rights and ownership, while Socialism/Communism stands 
on Strict Egalitarianism, which believes in collective ownership and restricts individual freedom. Today, it can be said that the recent economic system of Neo-liberalism constricts the scope of the state's authority in favor of the individual. The goal is to achieve economic welfare by giving the individual full freedom. However, state's intervention will hold individual freedom.

The need for a role for the state or central authority is undeniable as human welfare cannot be reached in isolation from a social system and cooperative framework. Economic activities need to be secured through a government system with some moral restrictions on implementation, and the system is responsible for all the given roles. This role of state is to create justice for the economic system.

From this point of view, the Quranic principles ${ }^{42}$ strictly state that the state has a role in arranging and establishing social-economic justice. This principle is different from Nozick's Libertarian Principle which is unwilling to legitimize state intervention in the economy. The theory of entitlement is proposed by Nozick to keep the minimal state. The minimal state in Neo-liberalism was defeated through privatization, deregulation, and liberalization. Meanwhile Rawls' Principle adopted primarily to maintain the welfare state has a central position between Capitalism and Socialism (even Rawls himself never invites state's intervention explicitly).

Three important roles of the state in the intervention of economic activity are relatively limited, namely a case where the state is the owner and producer, the state is the redistributors over wealth and income, and the state is the regulator of economic life.

The first role reflects that anything related to the needs of citizens to live should be under the state's control where both ownership and

${ }^{42}$ QS. al-Hadid 57:25; and al-Nisā' 4:59. 
production should be under public ownership. Similarly, companies operating products of natural and environmental resources should be controlled by the state for the maximum welfare (al-falāh) of the citizens. This principle is different from what is believed by Libertarian and Classic Liberalism which stand on self-interest. Therefore, the two principles need privatization over all the resources with no exception due to efficiency and equal distribution. The extensive government's role towards ownership means violation over private rights and ownership.

The second role assures that in the process of distribution we do not stress one of any production factors, and exploit other. Resources such as land, workers, capital are in the same level of necessity. Therefore, the owner of the land, workers, and capital should share their product. Besides that, the Quran strictly demands that part of the product should be given to those who do not give any contribution but they have social, physical, and economical handicaps. Once again, it is obvious from the Quranic principle that someone may get rewards without considering their actual contribution.

The third role is regulation of citizen's consumption behavior and market regulation. This role in one side is an antithesis over Libertarian Principle which asserts that for the sake of absolute rights of the disproportional dividing world, private ownership is reasonable and free market in capital and work are morally needed. Free market is a mechanism for equal allocation and distribution. Thus, state's intervention should be defeated. Practically, Libertarianism is implemented by Neoliberalism which tries to delete public subsidy for society due to extravagance reasons, and at the same time multinational corporations (MNCs) and transnational corporations (TNCs) require tax holidays. Therefore, Neo-liberalism should claim the process of deregulation, which hints at the free market being economically profitable for the small part of the 
conglomerate. This is a paradox which is contradictory to justice (al'adl) and threatens public welfare (al-falah ). In the other side, the Quranic principle offers an alternative for market ethics to avoid speculative activity and gambling (gharar).

Table 3

Comparison on the theoris of state' roles and its implications

\begin{tabular}{|c|c|c|}
\hline Theory & Principle & Implication \\
\hline Libertarianism & $\begin{array}{l}\text { Free market in capital and work } \\
\text { are morally needed. }\end{array}$ & $\begin{array}{l}\text { Minimal State; state authority is } \\
\text { limited through deregulation and } \\
\text { privatization, and liberalization. }\end{array}$ \\
\hline $\begin{array}{c}\text { Strict } \\
\text { Egalitarianism }\end{array}$ & State intervention is absolute & Totalitarian State \\
\hline $\begin{array}{l}\text { The Quranic } \\
\text { Ethics }\end{array}$ & $\begin{array}{l}\text { State intervention is certainty } \\
\text { for ethical market creation. }\end{array}$ & $\begin{array}{l}\text { Role of states as owner, producer, } \\
\text { regulator, and redistributors, are } \\
\text { complementary for ethical market. }\end{array}$ \\
\hline
\end{tabular}

The role of the state in intervening in people's lives, including their economic life, is acknowledged. The Quran supports freedom and does not support any unimportant restrictions. Therefore, the roles of state here should be complementary towards the market's role in securing justice allocation and distribution of resources through total and ethical competition. Therefore, restrictions on the role of states are for the sake of maintaining justice ( $a l-' a d l)$ and primarily public welfare (alfalāh).

\section{Goals and implications}

According to the Quran, the ultimate goal of human life is to achieve welfare (falāh) in the day of resurrection. The day of resurrection is the continuity of worldly reality; what we will get in the hereafter is the rewards of our activities (productivity) in this world. Mundane falăh will lead man to faläh in the day after death. This is stated in verse: "when the call is proclaimed to prayer on Friday, hasten earnestly to the 
remembrance of Allah, and leave off business. That is best for you if ye but knew1"43

Justice guiding man's economic activities to reach falāh (happiness, welfare) in secular life is a large concept. In detail al-Raghib al-Asfahani divided falăh into two: happiness in this world and happiness in the day of resurrection. The former covers al-baqā', al-ghinā and al-'izz. While the later includes baqā' bilā fanā', ghinā bilā faqr, 'izz bilā dhull, and 'ilm bila jahl. ${ }^{44}$ When it is connected to economic activities, the first is most relevant to this discussion. This concept covers individual and collective welfare. The Quran names the former as hayāh tayyibah, ${ }^{45}$ and the later as baldah tayyibah. ${ }^{46}$

These two types of welfare also cover the following three important indicators:

1. Survival and sustainability indicators (al-baqā') which include: a) productive activities and professional work (al-bāqiyāt); ${ }^{47}$ b) taking profit in the right manner (al-baqiyyah); ${ }^{48}$ and c) having ecological consciousness (ülū baqiyyah). ${ }^{49}$

2. Productivity and well-being life indicators (al-ghina) which comprise of: a) working and avoiding to be a parasite on others; ${ }^{50}$ and b) freedom from poverty and impoverishment. ${ }^{51}$

${ }^{43}$ Abdullah Yusuf Ali, The Holy Quran: English Translation of the Meaning and Commentary, Makkah: The Presidency of Islamic Researches, IFTA, Call and Guidance, 1413; al-Jumu'ah 62:9, 1747-1748.

${ }^{44} \mathrm{Al}$-Raghib al-Asfahani, al-Mu'jam al-Mufradāt Alfāz\} al-Qur'ān, Beirut: Dār al-Fikr, NA, 399. ${ }^{45} \mathrm{QS}$. al-Naḥl 16:97.

${ }^{46}$ QS. Saba' 34:15.

${ }^{47}$ QS. Maryam 19:76; al-Kahf 18:46.

${ }^{48}$ QS. Hūd 11:86.

${ }^{49}$ QS. Hūd 11:116.

${ }^{50}$ QS. al-Tawbah 9:28.

${ }^{51}$ QS. al-Nūr 24:33. 
3. Self-esteem and magnificence indicators (al-'izz) ${ }^{52}$ which cover: a) maintaining self-esteem and not begging from others; and b) freedom from debt (both domestic and foreign).

Thus, it is obvious that falāh, which becomes the goal of justified economic activities is a comprehensive concept and it includes many levels of welfare. Ideally, Islam urges people to make an effort in achieving their ideal. By relating the nature of justice and falăh, it will be clearer that justice has close relations to welfare. A sense of justice will bear in the form of happiness, and happiness is a display of a sense of justice, so the relation between justice and welfare is mutual or reciprocal.

Maintaining a sense of justice and applying its principles in reaching a state of happiness will result in some implications in the process of institutionalization through: (1) establishing values of justice as motives for action in economic activities; (2) realization of religious obligations and virtues in economic activities; (3) maintaining socio-economic management in just, humanistic, environmentally friendly manners; (4) implementing the role of the state in running political systems and policy which emphasizes justice and welfare.

\section{Conclusion}

Problems of injustice, and, failures of economic systems and contemporary justice theories in answering these problems, leads to rethinking of justice economic theory and this is still relevant where contingency, scarcity and powerlessness of the people are increased among the haves piling up wealth. You need to break this down into smaller sentences). Justice as the foundation of economic activities and policy has an important position in the discussion about the contemporary eco-

\footnotetext{
${ }^{52} \mathrm{QS}$. Âlu 'Imrān 3:26.
} 
nomic system. Islam - as a religion as well as a way of life - also tries to take part in giving direction as to what, how and where justice should be addressed in economic activities.

Dealing with injustice and offering authentic values of justice in a dialectical situation where many economic systems compete with each other, then the previous discussion have given some alternatives for overcoming injustice, its implementations and teleological dimension in relating to distribution..

The detailed description mentioned above reflects the conceptual answer of the Quran on the problem of distributive and redistributive injustice, where some principles of economic justice can be inferred as follows:

1. distribution of natural and environmental resources are in the framework of participation and partnership;

2. redistribution of wealth and income are responsibilities in guaranteeing social security, capacity and authority improvement for the disadvantaged;

3. the role of states as redistributors are complementary for ethical markets to secure a sense of justice and the achievement of public welfare.

It is time for economic systems and activities to take consideration of the continuance of natural and environmental resources as important variables in sustainable development. Moreover these variables are important in completing the five maqāșid al-shari'ah- hifz al-din,

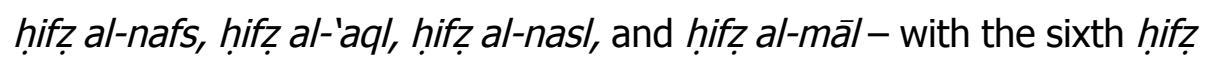
$a l-b i ' a h$, that is environment protection and conservation.

Conceptions of economic justice in Islam, its principles of justice and goals as mentioned above, determine the moral principles to be established and internalized in economic institutions. These institutions will 
determine how everyone struggles for life, enters into contracts and transactions, exchanges goods and services with each other, and produces core materials independently for the sake of their own economic lives. Through these principles, economic justice does not merely give freedom for creative involvement in economic oriented-works but it becomes part of their soul and spiritual life.

In establishing principles of justice within economic institutions, this study has some limitations such as: first, due to qawliyyah approach, the principles thematically deducted are normative, thus, in the next study, kawniyyah approach is needed to ensure empirically whether the normative principles of justice find verification or falsification from the available facts; second due to its normative character, the principles of justice require a proceeding study which is as important as focusing on the pragmatic interpretation for the operational needs of its implementation.

Economic justice systems involve individuals and social order. Therefore, any economic justice system requires reciprocal interrelations with the social justice system which has been discussed widely in Islamic thought. This study implies the importance of sensitiveness in relation to ecological justice. Ecological justice is significant as it relates closely to the activities of production and consumption of renewable resources and un-renewable resources, as well as the direct and indirect impacts to sustainability of all creatures. Ecological justice is based on sustainability on which the future depends. Regarding the importance of green investment and environmental conservation, a study on ecological justice is greatly needed. 


\section{Bibliography}

Adnan, M. Akhyar. Akuntansi Syariah: Arah, Prospek dan Tantangannya. Yogyakarta: UII Press, 2005.

Ali, Abdullah Yusuf. The Holy Quran: English Translation of the Meaning and Commentary. Makkah: The Presidency of Islamic Researches, IFTA, Call and Guidance, $1413 \mathrm{H}$.

Asfahani, al-Raghib. Al-Mu'jam al-Mufradāt Alfāẓ al-Qur'ān. Beirut: Dār al-Fikr, NA.

Asqalani, Ibn Hajar. Fatḥ al-Bārỉ Sharh Șahịḥ al-Bukhārỉ. Beirut: Dār alMu'arrafah, NA.

Bruce, Maurice. The Coming of the Welfare State. London: Batsford, 1968.

Bukhari. Șahịh. Indonesia: Dār Iḥyā' al-Kutub al-'Arabiyah, 1981.

Chapra, M. Umer. Islam and the Economic Challenge. Herndon: IIIT, 1992.

Daud, Abu. Sunan. Beirut: Dār al-Fikr, NA.

Dworkin, Ronald,"What is Equality? Part 1: Equality of Resources", Philosophy and Public Affairs, 10 (1981): 185-246.

Dworkin, Ronald,"What is Equality? Part 2: Equality of Welfare", Philosophy and Public Affairs, 10 (1981): 283-345.

Fakih, Mansour. Bebas dari Neo-liberalisme. Yogyakarta: Insist Press, 2003.

Fukuyama, Francis. The End of History and the Last Man. New York: Avon Books, 1992.

Furniss, Norman and Tilton, Timothy. The Case of Welfare State: From Social Security to Social Equality. Bloomington, Indiana: International Union Press, 1977. 
Goodin, Robert E. Utilitarianism as a Public Philosophy. New York: Cambridge University Press, 1995.

Hanbal, Ahmad ibn. Al-Musnad. NP.: al-Maktabah al-Islāmì, NA.

Majah, Ibn. Sunan. Beirut: Dār al-Fikr, NA.

Manzur, Ibn. Lisān al-'Arab. Beirut; Dār al-Ṣadr, 1990.

Miller, David. Social Justice. Oxford: Clarendon Press, 1976.

Miller, David. Market, State and Community. Oxford: Clarendon Press, 1989.

Muslim. Șahịh. Beirut: Dār al-Fikr, 1991.

Nielsen, Kai,"Radical Egalitarian Justice: Justice as Equality" Social Theory and Practice (1979): 209-226.

Nozick, Robert. Anarchy, State and Utopia. New York: Basic Books, 1974.

Rawls, John. A Theory of Justice, $22^{\text {nd }}$ printed. Cambridge, Massachusetts: The Belknap Press of Harvard University Press, 1997.

Riley, Jonathan,"Justice Under Capitalism," in John W. Chapman (ed.). Market and Justice. New York: New York University Press, 1989: 122-162.

Shihab, M. Quraish. Wawasan al-Quran: Tafsir Maudhu'i atas Pelbagai Persoalan Umat. Bandung: Mizan, 1996.

Turmudhi. Sunan. Beirut: Dār al-Fikr, 1994. 